\title{
MEMPERBAIKI TRADISI KEILMUAN
}

\author{
Retna Dwi Estuningtyas ${ }^{1}$ \\ ${ }^{1}$ Universitas Ibnu Chaldun (UIC) Jakarta \\ E-mail: reretnadwiegmail.com, Tlp: +6282312481112
}

\begin{abstract}
Abstrak
Tradisi keilmuan bisa kita pahami sebagai pemahaman ilmu pengetahuan secara turun menurun dari para pendahulu yang senantiasa diikuti terus menerus. Ilmu yang ada yang diwariskan dalam masyarakat Islam juga bermacam ragam. Adapun ilmu yang dipahami adalah ada ilmu aqliyah maupun naqliyah. Kedua macam ilmu ini sangatlah diperlukan manusia untuk mengatasi berbagai persoalan hidup yang ada. Keduanya harus dimiliki untuk kebaikan dunia dan akhirat. Keduanya amat diperlukan untuk umat Islam saat ini karena sedang mengalami kemunduran. Umat Islam saat ini sangat terpuruk dan terbelakang dalam ilmu pengetahuan dan teknologi, padahal sesungguhnya umat Islam dulunya sangat hebat dalam ilmu pengetahuan. Di mana bangsa Barat dan Amerika masih bodoh. Mereka dulunya adalah para pemimpin dalam ilmu pengetahuan. Namun saat ini umat Islam mengalami kemunduran. Ini disebabkan oleh faktor politik dan penjajahan ekonomi. Oleh karena itu perlu diupayakan upaya memperbaiki tradisi keilmuan, agar kejayaan umat Islam dapat kembali diraih.
\end{abstract}

Kata Kunci: Ilmu, Pengetahuan, Teknologi

\begin{abstract}
We can understand about the scientific tradition as the understanding of science in a downward manner from the predecessors who are constantly being followed. Existing knowledge inherited in Islamic societies is also diverse. The knowledge that is understood is that there is aqliyah and naqliyah knowledge. Both types of knowledge are very necessary for humans to overcome various life problems that exist. Both must be owned for the good of the world and the hereafter. Both are very necessary for Muslims today because they are experiencing setbacks. Muslims today are very poor and backward in science and technology, whereas in fact Muslims used to be very great in science. Where Westerners and Americans are still stupid. They used to be leaders in science. But at this time Muslims are experiencing setbacks. This is caused by political factors and economic colonization. Therefore, efforts need to be made to improve the scientific tradition, so that the glory of Muslims can be achieved, again.
\end{abstract}

\section{Keywords: Science, Knowledge, Technology}

\section{PENDAHULUAN}

$\mathrm{I}$ slam adalah agama yang mengajarkan umatnya untuk selalu belajar. Islam mengajarkan umatnya untuk selalu menggunakan akal pikiran yang sudah dikaruniakan Allah kepada manusia (QS al-Nahl/16: 78). Islam juga agama yang memposisikan ilmu dalam posisi mulia. Sebagai tanda keutamaan ilmu dalam Islam adalah sifat ilmu adalah salah satu sifat wajib Allah SWT (Ahmad Satori dan Ismail, 2003: 48).

Manusia adalah makhluk yang sempurna. Manusia pertama yang Allah ciptakan, langsung mendapatkan pelajaran tentang apa-apa yang ada di surga oleh Allah (QS. al-Baqarah/2: 30-33). Ayat ini pun menunjukkan pada kita, bahwa Islam adalah agama ilmu pengetahuan, dimana kita semua 
mempunyai potensi untuk mengembangkan apa yang sudah kita miliki bersama, yaitu akal pikiran kita yang merupakan anugerah Allah yang luar biasa.

Mempelajari sesuatu adalah mempelajari sebuah ilmu. Ilmu yang ada membuat manusia lebih baik. Dengan ilmu manusia dapat mengarahkan perilakunya, dengan perasaannya manusia mendapatkan kesenangan. Kombinasi keduanya membuat hidup manusia lebih terarah, masuk akal dan bermanfaat. Tidak dapat disangkal bahwa ilmu sangat berperan dalam kehidupan manusia, maka bekali diri kita dengan ilmu yang bermanfaat sebanyak-banyaknya.

\section{A. Ruang Lingkup Kajian}

Secara substansial, lingkup kajian yang diteliti adalah hal-hal yang membahas tentang ilmu dan keilmuan termasuk mengkaji ayat-ayat tentang ilmu yang tersebar sangat banyak di al-Qur'an. Dalam tulisan sederhana ini akan dikaji bagaimana memperbaiki tradisi keilmuan yang selama ini dipahami terdikotomi. Tentunya kajian ini harus menggabungkan metode penelitian pustaka dan kualitatif, di mana dalam kajian yang dilakukan mencermati hubungan keilmuan dalam sejarah dan faktor yang mempengaruhi kemunduran umat Islam dalam hal keilmuan.

Dengan mengumpulkan dan mendefinisikan ayat-ayat al-Qur'an yang berhubungan dengan keilmuan, data-data kekinian (kondisi) dan ilmu yang kita pelajari bersama. Maka diharapkan didapatkan suatu metode baru dalam memperbaiki tradisi keilmuan yang sudah ada.

\section{B. Rumusan Masalah}

Mengingat ruang lingkup permasalahan yang sangat luas, maka permasalahan penulisan ini perlu dibatasi untuk mencapai sasaran yang menjadi objek kajian, sehingga pembahasan lebih terarah pada pokok masalah. Ini dimaksudkan agar terhindar dari pembahasan yang tidak ada relevansinya. Oleh karena itu penulis membatasi hanya pada memperbaiki tradisi keilmuan.

Perihal lain yang turut dibahas karena masih ada kaitannya, hanyalah merupakan kerangka landasan atau studi banding dalam memecahkan masalah ini. Adapun perumusan masalahnya adalah :

1. Apakah ada pertentangan antara agama Islam dengan ilmu pengetahuan?

2. Seberapa penting usaha memperbaiki tradisi memahami ilmu pengetahuan dalam perspektif agama Islam sebagaimana yang terkandung dalam al-Qur'an?

\section{PEMBAHASAN}

\section{Memperbaiki Tradisi Keilmuan}

\section{Tradisi Keilmuan}

Tradisi adalah sesuatu hal yang diwarisi turun temurun dari pendahulu kita (Paul B. Horton dan Chester L. Hunt, 1991: 211). Tradisi sifatnya selalu stagnan dan kurang berkembang, ini dikarenakan semua adalah warisan leluhur. Tradisi ini bentuknya pastilah bermacam-macam, salah satunya adalah keilmuan, atau tradisi keilmuan. 
Tradisi keilmuan bisa kita pahami sebagai pemahaman ilmu pengetahuan secara turun menurun dari para pendahulu yang senantiasa diikuti terus menerus. Ilmu yang ada yang diwariskan dalam masyarakat Islam juga bermacam ragam, akan tetapi ilmu tersebut secara garis besarnya dapat kita klasifikasikan berdasarkan sifatnya ada dua macam, yaitu:

a. Ilmu yang terpuji.

Ilmu yang terpuji ada dua macam pula, yaitu fardlu 'ain dan fardlu kifayah (Ahmad Satori dan Ismail, 2003: 46). Ilmu yang fardlu 'ain adalah, mengetahui aqidah yang benar, mengetahui apa-apa yang harus diimani, mengetahui kewajiban-kewajiban dan ibadah yang harus dilaksanakan dan mengetahui hal-hal yang harus ditinggalkan.

Ilmu yang fardlu kifayah adalah, ilmu yang berkaitan dengan maslahat dunia, seperti ilmu hitung, astronomi, kimia, bahasa, industri, pertanian, dan sebagainya.

b. Ilmu yang tercela.

Ilmu yang tercela adalah ilmu yang membahayakan, seperti ilmu sihir, perdukunan, meramal, bahkan Islam menganggap sebagai dosa besar yang harus dijauhi (Ahmad Satori dan Ismail, 2003: 46).

Kedua macam sifat ilmu tersebut di atas senantiasa mewarnai kehidupan manusia. Sedangkan berdasarkan jenisnya ilmu diklasifikasikan juga menjadi dua yaitu:

1) Ilmu 'Aqliyah.

Ilmu 'aqliyah adalah ilmu yang berhubungan dengan akal manusia. Ilmu 'aqliyah bisa juga kita katakan sebagai hasil budi daya akal manusia, atau hasil pemikiran manusia yang bersungguhsungguh untuk mengubah dunia menjadi lebih baik (Musyrifah Sunanto, 2007: 110). Termasuk disini adalah ilmu fisika, kimia, kedokteran, perdagangan, dan masih banyak lagi. Ini biasa juga di sebut sebagai ilmu kauniah.

2) Ilmu Naqliyah.

Ilmu naqliyah adalah ilmu yang berhubungan dengan segala hal dalam al-Qur'an dan Hadist Nabi (Musyrifah Sunanto, 2007: 110). Orang lebih cenderung mengatakan bahwa ilmu naqliyah adalah ilmu-ilmu yang berhubungan dengan keagamaan. Yang termasuk di dalamnya adalah ilmu tafsir, ilmu tajwìd, 'ulüm al-ḥadis, 'ulüm al-Qur'ān dan banyak lagi yang lain. Ini biasa juga di sebut ilmu syari'ah atau ilmu usūùl.

Kedua macam ilmu ini sangatlah diperlukan manusia untuk mengatasi berbagai persoalan hidup yang ada. Keduanya harus kita miliki untuk kebaikan dunia dan akhirat kita. Keduanya amat diperlukan untuk umat Islam saat ini karena sedang mengalami kemunduran.

Umat Islam saat ini sangat terpuruk dan terbelakang dalam ilmu pengetahuan dan teknologi, padahal sesungguhnya umat Islam dulunya sangat hebat dalam ilmu pengetahuan. Dimana bangsa Barat dan Amerika masih bodoh. Mereka dulunya adalah para pemimpin dalam ilmu pengetahuan. 
Namun saat ini umat Islam mengalami kemunduran. Ini disebabkan oleh faktor politik dan penjajahan ekonomi (Sya'labi, t.th., 265).

Umat Islam saat ini terbalik mengalami kemunduran, ini berbeda sekali dengan jaman keemasan Islam dahulu, dimana pada saat itu bangsa Barat masih gelap gulita dan belum mengenal peradaban. Pada saat itu banyak orang barat yang belajar kepada kaum muslimin. Universitasuniversitas dan sekolah Islam di Andalusia dan Sisilia dan Syam adalah pusat-pusat keilmuan, dimana orang-orang Eropa banyak belajar di sana. Pengetahuan yang mereka dapat di sana adalah pondasi kemajuan Eropa. Sebenarnya orang-orang Eropa banyak belajar dari umat Islam, namun sekarang kaum muslimin sangat terpuruk dibanding mereka (Sya'labi, t.th., 265).

\section{Ilmu Pengetahuan di Tengah Umat Islam}

Banyak sekali ilmuwan Islam dengan karya-karya mereka yang besar, yang pengaruh dan hasil karya ilmiahnya masih dirasakan hingga berabad-abad kemudian dalam perkembangan ilmu pengetahuan di Eropa. Para cendekiawan barat mengakui bahwa Jabir Ibnu Hayyan (721-815) adalah orang pertama yang menggunakan metoda ilmiah dalam kegiatan penelitiannya dalam bidang alkemi, yang kemudian oleh ilmuwan Barat diambil alih dan dikembangkan menjadi ilmu kimia yang kita kenal sekarang. Jabir atau dalam nama latinnya Geber adalah orang pertama yang mendirikan bengkel yang menggunakan tungku untuk mengolah mineral-mineral dan mengekstrasi zat-zat kimia serta mengklarifikasikannya (Achmad Baiquni, 1994: 119).

Di dalam sejarah ilmu pengetahuan yang ditulis oleh para sarjana Eropa disebutkan bahwa Muhammad Ibnu Zakaria Ar-Razi (865-925) telah menggunakan alat-alat khusus untuk melakukan proses-proses yang lazim dilakukan ahli kimia seperti distilasi, kristalisasi, kalsinasi dan sebagainya. Buku Ar-Razi, yang namanya dilatinkan menjadi Razes, dianggap sebagai manual atau buku pegangan laboratorium kimia yang pertama di dunia, dan dipergunakan oleh para sarjana Barat yang baru berabad-abad kemudian belajar sains yang mana telah dikembangkan umat Islam, di universitasuniversitas Islam di Toledo dan Kordoba maupun Baghdad (Achmad Baiquni, 1994: 119-120).

Sekitar tahun 1231 ketika Henrick Harpestraeng, dokter Istana Raja Eric IV Waldermarsson, berusaha menulis risalah kedokteran dalam ilmu bedah di Salerno, (naskah itu sekarang tersimpan sebanyak tujuh jilid di Perpustakaan Nasional di Stockholm) ia meminta bantuan Michael the Scott, alumni Universitas Islam di Toledo, untuk dapat menggunakan buku-buku standar Ar-Razi dan Ibnu Sina yang berbahasa Arab tersebut sebagai sumber. Sesungguhnya masih banyak ilmuwan Islam yang mempunyai andil besar terhadap pengembangan ilmu pengetahuan pada masa lampau. Profesor Fuat Sezgin, Guru Besar Sejarah di Universitas Frankrut, telah menulis dua puluh jilid buku tentang karya-karya ilmuwan Muslim zaman lalu yang diberi judul Geschichte des Arabischen Schriftums, dan memberikan komentar tentang pengaruhnya pada ilmuwan Eropa kemudian, serta pembajakanpembajakan naskah yang disalin dari bahasa Arab untuk kemudian diakui sebagai karya ilmiah penyalin itu sendiri (Achmad Baiquni, 1994: 119-120). 
Beberapa orang beranggapan bahwa lenyapnya kemampuan umat Islam di bidang ilmu pengetahuan disebabkan oleh hancurnya sarana pengembangan ilmu dan perpustakaan karena mengamuknya tentara Mongol yang meludeskan Baghdad serta dihancurkannya kekuatan umat di Spanyol dan terbunuhnya banyak ilmuwan dalam peperangan itu. Namun fakta sejarah menunjukkan bahwa cucu Jengis Khan yang bernama Hulagu Khan, 60 tahun setelah Jengis Khan merusak, telah membangun observatorium bintang di Maragha, dimana Nasiruddin Al-Tusi merupakan tokoh utamanya. Memang suatu kerusakan selama beberapa dasawarsa dapat berpengaruh pada laju perkembangan ilmu. Namun selama masyarakat masih bersemangat untuk mengembangkannya, kegiatan ini tak akan pernah menjurus ke arah kematiannya seperti yang telah terjadi pada ilmu pengetahuan di lingkungan umat.

Sementara itu beberapa orang lain mencoba mencari penyebabnya dalam diri Imam Ghazali, dengan menunjuk pada kritik pedas yang dilancarkannya pada Al-Farabi dan terutama Ibnu Sina, tokoh rasionalis yang sangat berpengaruh di lingkungan ilmuwan pada waktu itu, dalam bukunya Taḥāfut al-Falāsifah. Orang-orang mengira bahwa pengaruh dan tradisi serta semangat ilmuwan yang rasional menjadi lenyap karenanya. Padahal karya imam Ghazali tersebut masih juga disanggah oleh Ibnu Rusyd yang terkenal sebagai tokoh yang rasionalis kira-kira satu abad kemudian (Achmad Baiquni, 1994: 120-121).

Tidak dapat dipungkiri bahwa kejadian-kejadian historis tersebut mempunyai andil masingmasing dalam pembentukan kondisi kegiatan ilmiah umat. Tetapi orang menyadari juga bahwa matinya suatu tradisi yang hidup dalam masyarakat, dalam hal ini adalah tradisi ilmiah, tradisi keilmuan, tidak mungkin disebabkan terjadi karena meninggalnya seorang tokoh ilmuwan atau terbitnya sebuah buku. Untuk itu diperlukan proses yang cukup lama dimana orang selalu mengulang-ulangi usaha atau kegiatan yang diharapkan dapat menghasilkan efek yang dikehendaki.

Karena umat Islam mengikuti perintah untuk mencari ilmu kapan saja, dari buaian sampai masuk kubur, dan dimana saja meski ke negeri Cina sekalipun, maka terdapat banyak buku yang disalin dari bahasa asing dan dipelajari, termasuk disini falsafah Yunani yang diajarkan oleh Socrates, Plato, Aristoteles dan Plotinus.

Pada saat itu para ilmuwan yang ternama mempelajari dan mengembangkan berbagai cabang ilmu pengetahuan. Mereka itulah yang mendapat julukan Al-Hakim. Khususnya Ibnu Sina yang hafal al-Qur'an pada umur 10 tahun dan menguasai ilmu pengetahuan seluruhnya yang berkembang pada masa itu pada usia 18 tahun. Ibnu Sina memiliki karya tidak kurang dari 250 buah dan menulis Kitab Al-Syifä' yang mengandung uraian-uraian tentang logika, matematika dan pengetahuan alam di samping kedokteran. Ia mendapat julukan Syaikh Ar-Rais di antara rekan-rekannya dan dikenal sebagai The Prince of Physicians di dunia Barat (Achmad Baiquni, 1994: 123).

Oleh karena pada zaman itu Imam Ghazali masih memasukkan metematika, logika, fisika, teologi, politik dan etika masuk dalam kelompok ilmu-ilmu filsafati, maka kritiknya kadang salah 
ditafsirkan orang sebagai penolakan. Bagi Imam Ghazali kritikannya diarahkan pada sasaran yang tepat, agar dalam membicarakan ilmu-ilmu itu tidak diberi bobot dalam pembicaraan mengenai masalah agama, kecuali bila ia juga ulung dalam masalah ilmu uṣūl. Jadi bila Imam Ghazali mengatakan bahwa "matematika tidak ada relevansinya dengan agama" bukan berarti melarang mempelajari matematika. Selanjutnya dalam kitabnya al-Munqiz̧u min al-Ḍalāl, ia menyatakan sebagai berikut:

"Kejahatan yang menyedihkan sungguh telah dilakukan terhadap agama oleh-orang yang berkhayal bahwa Islam tidak dapat dibela dengan mengingkari kebenaran matematika" (Achmad Baiquni, 1994: 124-125).

Mengenai logika, Imam Ghazali antara lain mengatakan sebagai berikut:

"Apabila pengingkaran semacam itu dilakukan terhadap ilmu logika maka pengaruhnya ialah bahwa para ahli logika akan kehilangan kepercayaan pada intelegensi orang yang ingkar tersebut, dan celakanya, juga pada agamanya yang mereka anggap ditegakkan atas pengingkaran-pengingkaran bodoh semacam itu."

Mungkin sekali dikotomi yang menghinggapi umat dewasa ini adalah usaha mereka yang kurang menghayati tulisan Imam Ghazali itu dan ingin menjauhkan pengikut-pengikut mereka dari pengaruh ilmu kauniah yang mereka sendiri tidak menguasai, agar pertanyaan yang kritis dari muridmurid dapat mereka hindari. Namun seandainya ilmu kauniah pada waktu itu sudah merakyat, dan diajarkan di madrasah-madrasah bukan hanya dikembangkan di Istana para Amir dan penguasa di mana tokoh-tokoh ilmuwan itu berada dan ikut meningkatkan gengsi mereka, proses itu mungkin tidak akan terjadi (Achmad Baiquni, 1994: 124-125).

Menurut banyak orang, ada kesan bahwa pintu ijtihad telah tertutup ini dikarenakan pada saat sekarang anggapan tidak ada mujtahid ulung di bidangnya. Sebetulnya anggapan itu tidaklah benar, karena pada saat sekarangpun kemampuan seseorang untuk menjadi mujtahid juga masih ada, banyak para ilmuwan Islam, para mufti, kita lihat saja seperti Syekh Yusuf al-Qaradhawi, dan apabila kita menemukan kelompok-kelompok yang berijtihad di bidang-bidang tertentu karena memang diperlukan usaha kelompok, maka kita bisa katakan itulah bentuk ijtihad kelompok. Jadi tidaklah benar bahwa pintu ijtihad telah tertutup.

Untuk mencapai kondisi yang merupakan syarat mutlak bagi penguasaan kembali ilmu pengetahuan, baik ilmu ushul maupun ilmu kauniah, maka generasi muda ini harus mendapat gemblengan yang sekeras mungkin. Selalu dihadapkan pada tantangan yang berat dalam memecahkan persoalan ilmiah, dan didorong untuk bekerja keras.

\section{Kebangkitan Barat}

Dengan adanya kemunduran tiga daulah Islam (Usmaniyah, Shafawiyah dan Mughal) maka berakhirlah zaman kejayaan Islam (sekitar abad XIII). Umat Islam satu demi satu jatuh dibawah kekuasaan Barat. Demikian pula ilmu pengetahuan hasil karya ilmuwan-ilmuwan Islam juga dibawa ke Barat. Mulailah di adakan sekularisasi, mulailah dihembuskan pembagian ilmu (dikotomi). Maka 
dunia Barat bangkitlah ilmu pengetahuan dan teknologinya. Tentunya bangkit pula perekonomiannya.

Akan tetapi kebangkitan Iptek di Barat sebenarnya adalah menghancurkan (Barat sendiri), bahkan mengancam kedamaian dunia secara keseluruhan. Banyak dana yang dihabiskan untuk membuat senjata yang seharusnya dana itu di peruntukkan untuk umat manusia. Karena masyarakat mereka sebenarnya tidak mengenal Tuhan, tapi masyarakat yang dibangun atas dasar sistem ekonomi dan membolehkan seseorang untuk membunuh yang lain untuk mendapat makan dan pakaian, tidak ada nilai-nilai moral dan iman (Sya'labi, t.th., 270).

Ini adalah kehancuran. Revolusi industri di Jerman adalah tujuan akhirnya, sebelum Perang Dunia II. Jerman sebenarnya adalah salah satu negara yang memiliki peradaban maju, namun kemudian menghancurkan jutaan umat manusia di sebabkan oleh perang yang mereka kobarkan. Yang mana menurut mereka hanya mengenal kekerasan dan membenci kemajuan (Sya'labi, t.th., 270).

Kita kenal dalam sejarah adanya Napoleon, yang juga membawa peradaban Islam dan menutup kebebasan mencari ilmu. Puncaknya adalah saat penjajahan Eropa terhadap Negara-negara Islam. Di mana saat itu bangsa barat menutup kebebasan berpikir mereka. Di mana tidak mungkin kebangkitan itu muncul dalam tekanan dan perbudakan (Sya'labi, t.th., 270).

Pada saat ini umat Islam juga banyak terpengaruh oleh tradisi Barat. Banyak hal, termasuk dalam kemanusiaan. Hal ini yang menjadikan umat Islam saat ini juga kurang memulyakan nilai-nilai kemanusiaan. Bukanlah masyarakat seperti yang kita inginkan, tapi masyarakat yang mengerti aturan dan memulyakan nilai-nilai kemanusiaan. Yang kita inginkan adalah masyarakat yang baik, bukan yang rusak. Cara mencapai adalah dengan menumbuhkan tradisi keilmuan dalam lingkungan yang mengerti agama dan akhlak. Sehingga akal tidak menjadi liar, tapi diikat dengan nilai-nilai keimanan dan akhirat. Ini adalah tradisi Islam atau hal yang seharusnya ada dalam lingkungan Islam.

Kaum muslimin mengalami kemunduran dalam tradisi keilmuan sehingga mereka sekarang harus mengambil peranan dalam terobosan-terobosan ilmu pengetahuan. Negara-negara Arab saat ini telah menunjukkan peranannya. Hal ini kemudian diikuti Negara-negara Islam yang lain. Kita di sini tidak akan membincangkan persoalan fiqh. Telah lewat masa itu, tapi yang jelas kita tahu, dulu umat Islam mempunyai laboratorium untuk penelitian yang bebas. Ini semua akan membawa kaum muslimin kepada kemajuan dan kebangkitan dan kemandirian ekonomi. Salah satu penjajahan modern saat ini adalah lewat jalur politik dan ekonomi. Mereka tidak segan-segan mengeluarkan banyak dolar untuk melakukan penjajahan. Kita semua tahu apa yang terjadi dengan kaum muslimin di India, dimana mereka dijajah oleh Inggris. Di satu sisi dan orang-orang Hindustan di sisi yang lain. Kita semua tahu bahwa masa itu banyak terjadi masalah antara India dan Pakistan. Letak Pakistan membuat negeri Islam ini meyakini bahwa India adalah musuh terbesarnya (Sya'labi, t.th., 276). 
Bukan hanya masalah senjata saja yang diperlukan oleh dunia Islam, namun juga berbagai macam ilmu pengetahuan. Kita perlu memajukan perdagangan, sehingga memiliki kemajuan ekonomi yang nantinya membuat kita merdeka dalam hal politik. Khususnya bahwa negera-negara Islam adalah penghasil minyak terbesar, dan ini merupakan bahan utama dalam dunia industri. Disinilah kita harus mulai bangkit untuk merebut kembali kejayaan Islam.

\section{Upaya Memperbaiki Tradisi Keilmuan}

Kita sering sekali mendengar orang menyerukan kebangkitan kembali umat Islam dalam abad ini. Apakah yang diinginkan kalau bukan jika bukan menikmati lagi kejayaan yang telah hilang? Namun kita mengetahui bahwa dalam jaman modern ini kebangkitan suatu bangsa tidak mungkin terlaksana tanpa pengetahuan dan teknologi. Selama suatu bangsa ini lemah dalam bidang ilmu kauniah, ia tak mungkin dapat bangkit dalam dunia yang sangat kompetitif ini, dan selama ia dihinggapi penyakit dikotomi maka tak akan mampu keluar dari kelemahannya.

Bagaimana dikotomi dapat dilenyapkan dari lingkungan umat Islam? Tentunya dengan mengadakan perubahan sikap mental. Kita semua menyadari bahwa perubahan semacam itu tidak akan mudah dilaksanakan, apalagi jika sikap itu telah melekat selama ini selama berabad-abad dan turun temurun. Sebab kita harus menginsyafkan seluruh umat bahwa ilmu yang dikaruniakan Allah SWT kepada umat manusia untuk mencapai kebahagiaan dunia dan akhirat melalui wahyu yang dikumpulkan dan dibukukan dalam bentuk Kitab Suci al-Quran merupakan kesatuan (unity). Kita harus menujukkan kepada umat bahwa bagian ilmu yang merupakan pegangan untuk kehidupan di alam akhirat mempunyai perincian dalam ayat lain dan Sunnah Rasul yang harus terima seperti apa adanya dan bahwa bagian ilmu yang diperuntukkan bagi kehidupan di dunia mempunyai keterangannya dalam al-Qur'an, yang dengan panca indera telah dikaruniakan Allah kepada kita, harus kita periksa sendiri, kita analisa dan kita ambil kesimpulannya (Achmad Baiquni, 1994: 126).

Kita pasti tidak akan sukar untuk mengingatkan umat akan kewajiban mencari ilmu, seperti Hadist Nabi yang diriwayatkan oleh (Ibnu Majah, 1998: 81):

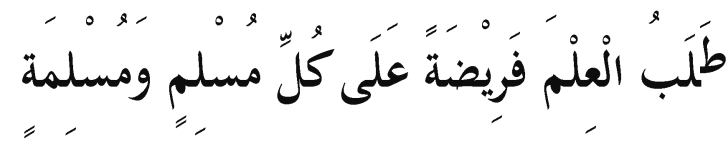

Artinya:

"Mencari ilmu adalah wajib bagi tiap muslim dan muslimah."

Apakah yang diwajibkan di sini menuntut semua ilmu yang bermanfaat atau hanya ilmu akhirat saja atau ilmu ushul, tidak termasuk ilmu dunia atau ilmu kauniah tidak diwajibkan mencarinya. Padahal Allah telah memerintahkan kita untuk mempelajari bahkan mengembangkan ilmu kauniah (Achmad Baiquni, 1994: 126).

Dalam Ihyyā' 'Ulūm al-Dỉn, Imam Ghazali menyatakan bahwa mencari ilmu yang digolongkan sebagai ilmu ushul hukumnya fardhu 'ain, seperti tentang kita harus tahu bagaimana berwudhu yang benar, berpuasa yang benar dan sebagainya. Mencari ilmu yang digolongkan sebagai ilmu kauniah 
yang berguna bagi masyarakat, hukumnya paling tidak fardhu kifayah, sebab ilmu kedokteran, ilmu hukum, ilmu militer, ilmu tehnik dan lain sebagainya diperlukan untuk keselamatan, keamanan dan tegaknya masyarakat muslim. Hal ini berarti apabila seluruh anggota msyarakat meninggalkannya, maka masyarakat itu, besar atau kecil, berdosa karena melanggar ketentuan dan akan mendapat hukuman Allah. Karena umat telah ternyata meninggalkan ilmu kauniah maka ia lemah dan penjajahan telah menimpa umat dalam segala bentuk dan coraknya cukup lama (Imam Ghazali, 2004: 10-11).

Bila kita masih ada orang yang meragukan bahwa mencari ilmu kauniah itu wajib, perhatikan Hadist Nabi yang diriwayatkan Ibnu Uda ini;

Artinya:

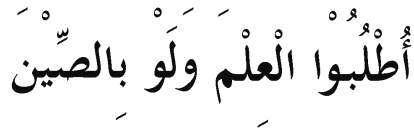

"Tuntutlah ilmu walau ke negeri Cina sekalipun."

Apa kiranya yang ada di Cina pada jaman Rasullullah? Dapatkah kita belajar ilmu agama di sana? Tentu tidak, karena mereka memeluk Islam saja belum. Dari fakta sejarah kita ketahui bangsa Cina sudah sejak jaman kuno mengenal ilmu pengobatan tradisional, astronomi, ramu-ramuan, dan banyak lagi pengetahuan yang tergolong ilmu kauniah. Jelaslah di sini bahwa menunt ut ilmu kauniah juga diperintahkan, dan merupakan kewajiban (Achmad Baiquni, 1994: 127).

Dengan perubahan sikap mental ke arah penghapusan dikotomi, terbuka kemungkinan bahwa umat Islam akan kembali memainkan peranan yang berarti di seluruh bidang atau cabang ilmu pengetahuan seperti sediakala, dan kebangkitan umat Islam akan menjadi kenyataan.

Bagaimana dengan ilmu syari'ah? Kita harus menggiatkan kembali agar tidak lagi terpuruk seperti sekarang dan kehidupan kita kembali mulia. Kita harus menyingkirkan segala rintangan yang menghambat perkembangan ilmu syari'ah ini. Dengan beberapa kiat seperti:

a. Mengembalikan sisi ruhiyah dalam studi ke-Islaman.

b. Berijtihad hanya dalam beberapa hal yang memiliki kesesuaian antara nilai-nilai keIslaman dengan kemaslahatan umat manusia. Tidak keluar dari prinsip-prinsip Islam dan menjelaskan hal-hal yang masih samar-samar dalam aturan-aturan Islam.

c. Mengambil manfaat yang sebesar-besarnya atas berbagai perbedaan madzhab yang ada.

d. Menegaskan kembali bahwa Islam diturunkan untuk manusia dan bukan untuk Malaikat.

e. Melakukan pendekatan budaya terhadap berbagai Negara Islam (Sya'labi, t.th.,: 273).

Semua ini memerlukan perjuangan berat,namun bila kita tidak segera memulainya, umat ini akan semakin terpuruk. Mengembalikan sisi ruhiyah dalam Islam ini, membuat kita perlu menulis ulang kitab-kitab Fiqh yang ada sekarang dengan spirit baru. Dalam hal ini menuliskan kembali kitab-kitab Fiqh tentunya tidak boleh keluar dari sumber utama yaitu al-Qur'an dan Hadist. Segala 
yang masih meragukan, yang kita kenal sebagai bahasan fiqh kontemporer tentunya perlu ditulis ulang dengan kajian yang lebih mendalam.

Demikian pula dengan kitab-kitab Tafsir dan meneliti kembali kitab-kitab Hadits. Juga menulis kembali kitab-kitab Hadits dan filsafat Islam. Menulis kembali sejarah peradaban Islam, bahkan kita mungkin harus kembali menulis ulang ilmu-ilmu lain yang ada kaitannya dengan studistudi keIslaman, seperti kaidah-kaidah bahasa Arab, balaghah, dan lain-lain.

Tampaknya hal ini begitu sulit, namun sesungguhnya perjuangan ini telah dimulai, sehingga nantinya kita akan mendapati semua studi Islam memiliki nilai-nilai ruhiyah dan jauh dari pembahasan dan perdebatan yang tak berguna,namun semuanya menampilkan keindahan Islam.

Dalam "Konfrensi Keilmuan Islam se Kawasan Asia-Pasifik" (regional Islamic Science Conference for Asia Pasific, RISCAP) yang berlangsung di Jakarta 12-15 Februari 1989, dihadiri para cendekiawan kawasan Asia-Pasifik tersaji sepuluh makalah yang utama yang berkaitan dengan perkembangan ilmu pengetahuan dan teknologi (iptek) dalam kaitannya dengan kehidupan masyarakat Islam di dunia di samping beberapa makalah lain. RISCAP diikuti para cendekiawan muslim dari kawasa Asia-Pasifik, baik perorangan maupun utusan lembaga pemerintahan dan swasta, terutama ahli ilmu pengetahuan dan teknik (M. Solly Lubis, 1997: 11-12).

Ada dua hal pokok yang menjadi bahasan utama dalam konfrensi tersebut. Pertama, upaya meningkatkan peranan nilai-nilai keIslaman dalam pengembangan iptek, baik dari segi ontologi maupun epistemologi dan orientasi aksiologinya. Kedua, upaya meningkatkan peranan potensi umat, baik dalam penguasaan iptek maupun dalam penggunaannya, sehingga umat mampu memegang peranan dalam meningkatkan taraf hidupnya sendiri dan umat manusia di dunia atas dasar ketakwaan kepada Tuhan Yang Maha Esa.

Pertimbangan untuk hal pokok pertama adalah situasi dunia dewasa ini, khususnya pengembangan dan penggunaan iptek yang lepas dari kendali keagamaan, sehingga cenderung kepada sikap kebuasan iptek yang melihat bahwa iptek semata-mata sebagai kekuatan atau kekuasaan untuk kepentingan pengaruh atau kekuasaan (knowledge is power). Sedangkan pertimbangan untuk hal pokok yang kedua adalah perlunya penyebarluasan kembali motivasi-motivasi keilmuan yang terdapat dalam kandungan al-Qur'an. Ini dimaksudkan agar umat Islam mampu berperan secara dominan dengan memanfaatkan potensi keilmuan dalam bimbingan nilai-nilai dan akidah Islam di semua bidang kehidupan manusia (M. Solly Lubis, 1997: 13).

Secara ontologis, dalam orientasi pilihan bidang ilmu dan teknologi yang relevan, diharapkan agar umat melihat betapa luasnya cabang ilmu yang tersedia di abad modern ini. Namun, betapapun luas cabang ilmu itu dalam pilihannya diharapkan agar manusia tetap berpegang pada tuntunan agama dan mematuhi suruhan dan larangan Allah SWT.

Secara Epistemologis, diharapkan agar pengembangan dan penggarapan ilmu pengetahuan itu, nilai-nilai akidah, dan kaidah keIslaman hendaknya tetap menjadi petunjuk (guidance) bagi ilmuwan. 
Dan secara aksiologis, supaya pemanfaatan iptek tetap dalam suasana mental dan perilaku yang takwa. Juga berusaha agar iptek membawa kesejahteraan bagi umat manusia, bukan saling merusak dan berbunuhan (M. Solly Lubis, 1997: 13).

Adalah demikian banyaknya ayat-ayat dalam al-Qur'an yang memotivasi manusia untuk melakukan studi, riset, dan diskusi mengenai alam raya yang penuh bukti akan kebesaran Allah SWT. Ini mendorong kita secara keimanan untuk memanfaatkan iptek bagi kesejahteraan manusia (M. Solly Lubis, 1997: 15).

Aspek-aspek ontologi, epistemologi dan aksiologi serta proses logika-hipotetiko-verifikatif yang dikenal dalam filsafat ilmu, pada hakikatnya telah ditemukan dasar-dasarnya dalam al-Qur'an bahwa al-Qur'an mengajarkan manusia agar secara ketuhanan dan kemanusiaan bertanggung jawab akan pemanfaatannya, baik secara vertikal kepada Allah maupun horisontal antar sesama manusia.

\section{Posisi Umat Islam Di Antara Bangsa lain.}

Kemajuan yang sangat pesat dalam sains dan teknologi pada abad yang ada di depan kita, menjadikan umat Islam mawas diri dalam posisi kita sekarang di antara bangsa-bangsa di dunia. Sejak umat Islam melepaskan kegiatannya dalam pengembangan iptek, kemampuan sains dan teknologi berpindah dari tangan umat Islam ke Eropa Barat, yang akibat dari sejarah memisahkan agama dari politik, ekonomi dan ilmu pengetahuan (sekularisme). Iptek dikembangkan dalam suasana yang sekuler, kemampuan umat di bidang ini semakin merosot. Usaha Kesultanan Turki untuk mengejar Eropa Barat dengan mendorong teknologinya mengalami kegagalan. Turki hanya mendapat teknologi yang cepat usang, sedangkan Eropa Barat yang menguasai sains sumber teknologi selalu memperoleh teknologi baru dari kegiatan sainsnya (Achmad Baiquni, 1994: 138).

Dibandingkan dengan umat beragama lain, Islam memang saat ini jauh ketinggalan, kita bisa lihat dari data-data yang ada dan kenyataan bahwa perekonomian dan teknologi dunia bukan lagi umat Islam yang menguasai, akan tetapi umat lain. Kalau ajaran Islam membimbing dan memacu serta memerintah pembudayaan iptek, mengapa begini keadaannya? Apakah umat Islam salah memahami ajaran itu?

Menurut Prof. de Solla Price, ada hubungan kesebandingan antara jumlah pakar (sainstis dan insinyur) yang melakukan riset dan pengembangan di suatu negara dengan GNP, yakni Produk nasional Brutonya, perkapita. Bagi negara maju yang sudah memahami perlunya iptek, maka penggunaan iptek akan secara optimal menun jang perekonomian dan kesejahteraan hidup mereka. Kelompok negara ini adalah Amerika Serikat, Inggris, Jerman Barat, Jepang, Belanda, Perancis.

Kita bandingkan dengan negara-negara berkembang yang mayoritas rakyatnya beragama Islam ( Pakistan, Indonesia, Nigeria, Turki, Yordania, Iran, Irak, Mesir, Arab Saudi) adalah berbanding terbalik, karena penggunaan iptek masih jauh dari optimal. Inilah keadaan umat Islam pada umumnya. Tengok saja negara kita tercinta, Indonesia, yang terdiri dari mayoritas muslim dan merupakan negara dengan populasi muslim terbanyak di dunia, telah kehilangan kesejahteraan di 
dunia dan nyaris kehilangan kesejahteraan di akhirat. Betapa tidak? Kita ingat saja, khususnya di Nusantara ini, bahwa pada zaman kolonial Snouck Hurgronje pernah mengusulkan kepada pemerintah Hindia-Belanda untuk melarang umat Islam pergi beribadah haji, kita tidak tahu rongrongan-rongrongan iman apalagi terhadap iman Islam penduduk Indonesia ini yang telah diolah dalam benaknya (Achmad Baiquni, 1994: 141).

Kini setelah merdekapun sebagian besar bangsa kita yang beragama Islam belum menikmati kesejahteraan duniawi, dan masih berjuang keras mengisi kemerdekaan itu. Kita masih berada dalam tahap pembangunan untuk mencapai masyarakat yang adil dan makmur, merata material dan spiritual dalam Negara Pancasila yang berlandaskan Undang-Undang Dasar 1945. Dan kita harus berhasil dalam pembangunan ini.

Namun kita perlu mawas diri, apakah kita telah benar-benar mensyukuri nikmat Allah yang berupa karunia sumberdaya alam dengan mengelolanyasesuai UUD 1945, pasal 33 dalam pengertian prinsip konservasi luas dapat dinyatakan sebagai pemanfaatan sebesar-besarnya bagi masyarakat yang seluas-luasnya untuk masa yang selama-lamanya (QS Ibrahim/14: 7).

Tapi sekali lagi, untuk dapat melakukan pengelolaan yang baik diperlukan kemampuan ilmu dan teknologi, yang pada umumnya belum kita kuasai, dibarengi dengan mental yang tangguh dan moral tinggi. Inilah salah satu masalah yang dapat kita identifikasi dan harus kita pecahkan. Untuk memperlihatkan relevansi antara ilmu pengetahuan dan teknologi bagi pembangunan, sebagai contoh adalah bagaimana Jerman dan Jepang yang dalam Perang Dunia Kedua telah dihancur leburkan kini bangkit kembali sebagi raksasa ekonomi yang disegani bekas lawan-lawannya.

Kini bangsa kita tengah giat-giatnya membangun dengan tujuan tercapainya masyarakat adil dan makmur yang merata material dan spiritual yang berdasarkan Pancasila. Pembangunan ini kita lakukan karena jika tidak berusaha keras untuk menghapus kebodohan dan kemiskinan yang diwariskan penjajah, tidaklah mungkin bangsa kita akan mencapai kesejahteraan apalagi kemakmuran seperti yang diidam-idamkan (QS al-Ra'd/13: 11).

Terwujudnya "Baldatun Toyyibatun wa Rabbun Gofür" yang dicita-citakan bangsa Indonesia kecuali memerlukan usaha yang keras dan terus- menerus untuk membangun manusia Indonesia yang seutuhnya. Hal ini berarti bahwa para pemegang peran dalam pembangunan Negara dan Bangsa ini tidak hanya harus dibekali ilmu keduniaan saja, melainkan harus dibekali juga ilmu keakhiratan. Mereka harus dididik untuk berakhlak, berilmu dan beramal. Bagaimana amal atau usaha dilakukan tanpa ilmu? Tentunya akan menjadi tidak berguna dan tidak tepat sasaran. tentunya ilmu yang diamalkan juga mesti disertai akhlak yang bagus.

Mendidik seseorang untuk berlaku jujur jauh lebih sukar daripada mengajarnya untuk melakukan perhitungan aljabar. Sebab sekali ia tahu cara menghitung maka ia akan mampu untuk seterusnya, ia akan mampu mengembangkan teori-teori aljabar tersebut. Akan tetapi orang jujur selalu mendapat godaan pada saat-saat tertentu untuk berlaku tidak jujur meskipun baginya jelas 
bahwa dorongan itu menjurus mendorong ke arah penyelewengan, meskipun dia tahu bahwa yang dia lakukan itu salah dan bertentangan dengan norma yang berlaku. Oleh karena itu akhlak harus dididik sejak kanak-kanak dan dibina terus-menerus. Oleh karena itu Islam mendahulukan pembinaan ilmu keakhiratan untuk menjadi landasan bagi penerapan ilmu keduniaan. Apabila ilmu dunia tidak didampingi oleh ilmu akhirat, maka ilmu itu akan menjadi liar, tidak terkendali, bahkan cenderung merusak (QS al-Qașaș/28: 77).

Gejala yang menampakkan diri sebagai ancaman pembangunan ini tidaklah mncul hanya di Indonesia saja, tetapi banyak di negara bekas jajahan dimana pada umumnya beragama Islam yang ingin meningkatkan taraf hidup dengan cara masing-masing. Keberhasilan dan mutu tergantung pada kemampuan masing-masing, baik kemampuan manajeman, organisasi, ilmiah, teknologi, ketrampilan dan sebagainya. Adakah kemampuan ini terhadap kita?

Indonesia mempunyai penduduk lebih dari 200 juta jiwa, dan memiliki sekitar 10 universitas ternama dengan fakultas matematika dan sains. Jumlah Guru Besar fisika yang mereka miliki sekitar 15 orang, pemegang Doktor di universitas tersebut kira-kira 40 orang. Bandingkan dengan satu universitas saja, seperti Imperial College of Science and Technology London, Inggris. Jumlah Guru Besar Fisikanya saja di sekolah ini ada sekitar 20 orang, pemegang gelar dokto 145 orang. Apakah hal ini tidak memilukan hati? Begitu lemah kemampuan kita dan itu tidak terbatas Indonesia, bahkan Pakistan yang di antara negara-negara Islam tergolong maju dalam sains dan teknologi, dengan 100 juta penduduk hanya memiliki 12 universitas dengan fakultas MIPA, Guru Besar seluruhnya hanya 20 orang, dalam bidang fisika, dan pemegang gelar Doktor untuk fisikanya hanya sebanyak 52 orang (Majalah wanita Ummi, edisi September, 2010: 21).

Untuk lebih meyakinkan diri betapa lemahnya umat Islam dalam bidang sains dan teknologi, data menunjukkan jumlah insinyur dan sarjana yang bekerja di bidang riset dan pengembangan di seluruh negara yang mayoritas penduduknya beragama Islam, adalah 55.000 orang diantara 700 juta jiwa. Bandingkan dengan Jepang yang memiliki 500.000 di antara 200 juta orang. Israel yang penduduknya hanya sekitar 4,5 juta jiwa memiliki tenaga penelitian dan pengembangan sebanyak 50.000 orang (Majalah wanita Ummi, edisi September, 2010: 21).

Apakah fakta-fakta ini tidak mengerikan? Padahal dari abad ke-VIII sampai dengan abad keXII, selama 500 tahun secara terus-menerus sains dan teknologi adalah monopoli umat Islam. Sejak abad XIII umat Islam secara berangsur-angsur mulai melepaskannya, mengangapnya sebagai unsur asing dan akhirnya menjauhinya atau malah memusuhinya. Sebagai akibatnya kita lemah, sedang Eropa mulai mengambil alih kedudukan kita sejak abad ke-XV dan kita umat Islam hidup dalam penindasan dan penjajahan selama berabad-abad sejak abad ke-XVII, karena kita tidak dapat menandingi teknologi persenjataan mereka dan kekuatan ekonomi mereka. Kita kehilangan kebahagiaan di dunia dan nyaris kehilangan kebahagiaan di akhirat, karena sarana peribadatan kita dengan mudah dapat dipotong oleh penguasa-penguasa itu (Achmad Baiquni, 1994: 138). 
Orang akhir-akhir ini mulai bicara tentang kebangkitan kembali umat Islam. Apa yang diinginkan dengan kebangkitan kembali itu kalau bukan untuk memperoleh kembali kejayaan yang telah terlepas itu? Akan tetapi dapatkah kita meraih kebesaran kita kembali? Dapat, asal kita benarbenar mempunyai keinginan yang keras untuk mencapainya dan mau bekerja keras untuk tujuan itu seperti yang disyaratkan dalam $Q S$ al-Ra'd/13: 11. Kalau kita hanya menginginkan kejayaan di dunia maka kita tiru bangsa-bangsa Barat, kita hanya berusaha menguasai sains dan teknologi yang bagus untuk menandingi mereka. Tapi kalau yang kita inginkan adalah kejayaan di dunia dan di akhirat, maka kita harus menguasai juga ilmu keagamaan, sebagaimana disabdakan Nabi Muhammad SAW:

"Barang siapa menghendaki keberhasilan untuk dunia, maka ia harus memiliki ilmunya, dan barang siapa menghendaki keberhasilan akhirat, maka ia harus memiliki ilmunya juga, dan barangsiapa menghendaki keduanya, maka ia harus menguasai kedua ilmu itu pula."

Kita mengetahui bahwa sebagaimana telah penulis uraikan di atas mempelajari ilmu syari'at adalah fardu 'ain, karena tiap pribadi muslim wajib mengetahuinya untuk dapat hidup sesuai dengan aturan-aturan Islam. Tetapi mempelajari sains dan teknologi, ilmu kedokteran, ilmu ekonomi dan kemasyarakatan, ilmu politik dan militer, dan lain-lain ilmu yang bermanfaat bagi kesejahteraan dan berdiri tegaknya umat, menurut Imam Ghazali dalam bukunya Iḥyā 'Ulüm al-Dīn hukumnya farḍu kifayah. Tidak tiap orang diharuskan menguasainya, tetapi dalam tiap kelompok masyarakat Islam, besar atau kecil, harus terdapat orang-orang yang mempelajari dan mengembangkannya. Bila tidak, maka seluruh masyarakat akan mendapat hukuman dari Allah SWT. Kita semua telah merasakan hukuman itu dalam bentuk penindasan, penghinaan dan penjajahan.

\section{PENUTUP}

\section{Kesimpulan}

Dari pembahasan panjang lebar di atas,, maka dapat diambil kesimpulan bahwa ilmu yang harus dipelajari oleh umat Islam adalah segala ilmu yang bermanfaat, untuk kemaslahatan, jadi tidak hanya ilmu akhirat saja akan tetapi ilmu dunia juga mesti dipelajari agar seimbang, tercipta masyarakat keilmuan yang kondusif. Dengan seimbangnya ilmu dunia dan akhirat tent unya keinginan mewujudkan masyarakat "Baldatun Toyyibatun wa Rabbun Gofür" yang dicita-citakan akan dapat diraih. Oleh sebab itu, pentingnya memperbaiki tradisi keilmuan di kalangan umat Islam agar dapat meraih kejayaan Islam kembali. Tentunya dengan meningkatkan peranan nilai-nilai keIslaman dalam pengetahuan iptek baik dari segi ontologi, epistemologi dan aksiologi. Juga upaya meningkatkan peranan potensi umat, baik dalam penguasaan iptek maupun dalam penggunaannya, sehingga umat mampu memegang peranan dalam meningkatkan taraf hidupnya sendiri dan umat manusia di dunia atas dasar ketakwaan kepada Tuhan Yang Maha Esa.

Selain itu diperlukan penyeimbangan antara ilmu dunia dan akhirat, harus berdampingan. Karena apabila ilmu duniawi tidak didampingi ilmu akhirat maka akan menjadi liar dan bahkan mugkin tidak berguna. Untuk memperbaiki tradisi keilmuan maka perlu juga menghindari atau 
meminimalisir segala bentuk pembahasan dan perdebatan yang tidak perlu, yang tidak berguna dalam hal studi Islam, karena perbedaan dan segala bentuknya adalah rahmat Allah, dan semuanya menampilkan keindahan Islam.

Umat Islam sendiri perlu mengadakan perubahan sikap mental, dengan menghapuskan dikotomi. Dengan begitu terbuka kemungkinan umat Islam akan kembali memainkan peranan yang berarti di seluruh bidang atau cabang ilmu pengetahuan seperti sediakala, dan kebangkitan Islam akan jadi kenyataan. Mempelajari ilmu syari'at adalah fardu 'ain, sedangkan ilmu-ilmu yang lain seperti sains, ekonomi dan sebagainya yang berguna untuk kemaslahatan umat adalah fardu kifayah.

\section{DAFTAR PUSTAKA}

Baiquni, Achmad. Al-Qur'an, Ilmu Pengetahuan dan Teknologi. Yogyakarta: Bentang Intervisi Utama pt, 1994.

Departemen Agama RI. Al-Qur'an dan Terjemahnya (Ayat Pojok Bergaris). Semarang: CV. Asy Syifa, 1998.

Ghazali, Imam. Ringkasan Ihya’ Ulumuddin, Upaya Menghidupkan Ilmu Agama

terjemahan.

Labib Mz. Ilmu dan Belajar. Surabaya: Himmah Jaya, 2004.

Horton, B. Paul dan Chester L. Hunt, Sosiologi, terjemahan, Aminuddin Ram, Tita Sobari. Cet. VI, Jakarta: Erlangga, 1991.

Ismail, Satori, Ahmad. Sepuluh Pilar Da'wah Di Era Globalisasi. Jakarta: Pustaka Tarbiatuna, 2003.

Lubis, Solly . M. Umat Islam Dalam Globalisasi. Cet. I, Jakarta: Gema Insani Press, 1997.

Majalah wanita Ummi. Ufuk Luar edisi September, 2010.

Sunanto, Musyrifah. Sejarah Peradaban Islam Indonesia. Jakarta: PT. Raja Grafindo Persada, 2007. Sya'labi. Mujtama' al-Islâmî. Beirut: Dar- Beirut: Dar al-Nafais. tth. 